\title{
Implementation of Fuzzy Inference Mamdani System Based on Graphic User Interface for the timing of planting rice on rice plants in traditional farming systems in South Aceh district
}

\author{
Amsar Yunan ${ }^{\mathrm{a}, 1, *}$, Sepri Kurniadi ${ }^{\mathrm{b}, 2}$ \\ ${ }^{1.2}$ Department of Computer Engineering, Polytechnic of South Aceh, Tapaktuan Indonesia \\ 1.amsar.yunan@gmail.com, ${ }^{2}$ seprikurniadi@gmail.com \\ *amsar.yunan@gmail.com
}

The agricultural sector plays an important role in a developing country that covers all economic life because it can become the main source of national income. Efforts that must be avoided are to avoid crop failure, one of the things that cause crop failure is that there is no match with the right planting period at the time of planting. So the purpose of this research is to build a decision-making system in the form of a system for determining planting time based on the traditional Aceh farming system. The process developed with information technology in the decision-making method using Mamdani fuzzy logic based on the Graphic User Interface by involving several criteria including the calculation of the month in the Hijri year, the calculation of days, the calculation of the time of planting, and the level of rainfall. So that when starting the process of planting rice traditionally, farmers with this system can choose the best time to grow crops in rice farming. This study used 40 samples as test data obtained from several villages in South Aceh Regency. The results of the study after testing, several classifications become decisions where the results that show very right are 2 respondents or $5 \%$, exactly 16 respondents or $40 \%$, less precise as many as 10 people or $25 \%$ and inaccurate as many as 12 people or $30 \%$. This study used 40 samples as test data obtained from several villages in South Aceh Regency. The results of the study after testing, several classifications become decisions where the results that show very right are 2 respondents or $5 \%$, exactly 16 respondents or $40 \%$, less precise as many as 10 people or $25 \%$ and inaccurate as many as 12 people or $30 \%$. This study used 40 samples as test data obtained from several villages in South Aceh Regency. The results of the study after testing, several classifications become decisions where the results that show very right are 2 respondents or 5\%, exactly 16 respondents or $40 \%$, less precise as many as 10 people or $25 \%$ and inaccurate as many as 12 people or $30 \%$.

Copyright (C) 2021 Politeknik Aceh Selatan. All rights reserved.

\section{Introduction}

The agricultural sector plays an important role in a developing country that covers all economic life because it can become the main source of national income. Sources of income from agricultural products have an important role, including food crops such as rice, corn, peanuts, soybeans which are important for national-scale security [1]. The thing that causes crop failure will occur if it is not following the right planting time in farming [2]. Research conducted by Ahmad Ridha and Sulaiman was carried out to determine the difference between revenues and costs by using the jajar legowo planting system with the traditional planting system, from the study obtained difference that the jajar legowo rice planting system showed a more appropriate level of opinion than the jajar legowo rice planting system. traditional planting system [3]. Furthermore, research conducted by Kharmila, et al (2019) related to the planting time of rice, corn, donkeys, and onions 
based on the water balance of plants, this study determined the planting time and water requirements of rice, corn, donkey, and onions. The results showed that areas with a sand texture had a relatively shorter planting period because this soil could not hold water longer in the soil which resulted in faster water grabbing. Rice plants are much more susceptible to drought when compared to the other three crops, so the risk of yield loss is also higher [4]. Furthermore, the following research utilizes the beginning of the rainy season, where the average number of rainy seasons is 50 millimeters in units of three successive bases, so it is necessary to consider the distribution of rainfall in the growing season using the Global Circulation Model method to predict daily rainfall in the growing season, i.e. predictions of future rainfall which can be given on time [5]. From the research that has been done by several previous researchers, the next research that will be carried out is to create a system for determining the timing of planting rice seeds in the traditional Aceh farming system using fuzzy Mamdani based on a graphic user interface that involves several criteria for calculating the Moon in the Hijri year, resulting in a work that can be utilized by Acehnese farmers as well as for use by those who need it in making decisions in determining planting time.

\section{Literature review}

\section{A. State of art}

The research that has been done by previous research on the system of starting to plant, as shown in table 1.

Table 1. State of art

\begin{tabular}{|c|c|c|c|}
\hline Model & Research Problem & Method & Results \\
\hline $\begin{array}{l}\text { Analysis of Rice Farmers' } \\
\text { Income on the Jajar } \\
\text { Legowo } \\
\text { System and the Tradititional } \\
\text { Cultivation System Case } \\
\text { Study in Matang Ara } \\
\text { Village, Jawa Kec. } \\
\text { Manyak Payed (Ahmad } \\
\text { Rida and Sulaiman, 2018) }\end{array}$ & $\begin{array}{l}\text { The low level of } \\
\text { income, ratio, and costs } \\
\text { incurred by farmers. }\end{array}$ & $\begin{array}{l}\text { jajar legowo planting } \\
\text { system }\end{array}$ & $\begin{array}{l}\text { The average income } \\
\text { level of farmers using } \\
\text { the jajar legowo system } \\
\text { is better than the } \\
\text { traditional system, the } \\
\text { ratio value for the jajar } \\
\text { legowo system is } 1.83 \\
\text { while the traditional } \\
\text { system is } 1.71\end{array}$ \\
\hline $\begin{array}{l}\text { Determination of planting } \\
\text { time and water } \\
\text { requirements for rice, corn, } \\
\text { soybeans, and shallots in } \\
\text { the provinces of West Java } \\
\text { and East Nusa Tenggara } \\
\text { (Kharmila, et al. 2019) }\end{array}$ & $\begin{array}{l}\text { Weather considerations } \\
\text { in the form of rainfall } \\
\text { become a very } \\
\text { important element } \\
\text { because it affects the } \\
\text { diversity of crop } \\
\text { production in the } \\
\text { tropics. }\end{array}$ & $\begin{array}{l}\text { Plant water balance } \\
\text { analysis }\end{array}$ & $\begin{array}{l}\text { Rainfall characteristics } \\
\text { of West Java have wet } \\
\text { months }>7 \text { months so } \\
\text { that it allows longer } \\
\text { planting time, namely } \\
\text { (on textured soils) dust: } \\
10-15 \text { basics, clay: } 8-14 \\
\text { basics, clay: } 8-13 \\
\text { basics, and sand: } 4-7 \\
\text { basics. While the dry } \\
\text { month of NTT is }>7 \\
\text { months, it is } \\
\text { recommended for corn } \\
\text { plants }\end{array}$ \\
\hline $\begin{array}{l}\text { Criteria for the Beginning } \\
\text { of the Planting Season: A } \\
\text { Review of Predicted Rice } \\
\text { Planting Time in Indonesia } \\
\text { (Elsa Suhaimi and Haris } \\
\text { Syahbuddin, 2016) }\end{array}$ & $\begin{array}{l}\text { Plant growth is not only } \\
\text { determined by rainfall } \\
\text { at the time of planting } \\
\text { but also the amount and } \\
\text { distribution of rain at } \\
\text { the time of planting }\end{array}$ & $\begin{array}{l}\text { Global Circulation } \\
\text { Model. Method }\end{array}$ & $\begin{array}{l}\text { Generating a model that } \\
\text { can predict daily } \\
\text { rainfall in the } \\
\text { upcoming growing } \\
\text { season can be provided } \\
\text { on time }\end{array}$ \\
\hline
\end{tabular}




\section{B. Fuzzy Logic or Fuzzy Inference System}

Fuzzy logic is one of the scientific fields of technology related to the formation of soft computing, the set as the input variable will be designed with rules so that a decision is made. As illustrated in Figure 1 below:

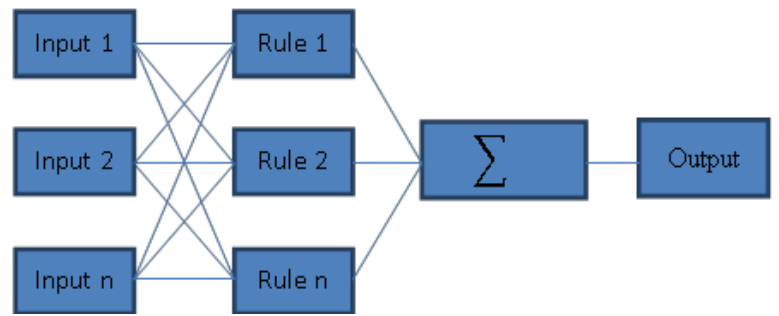

Figure 1. Mapping of the input-output process in the Fuzzy Inference System

A value in this fuzzy can be a large or false value simultaneously because in fuzzy the term membership degree has an interval of 0 (zero) to 1 (one). The first person to introduce fuzzy theory in scientific studies was Prof. Lotfi Zadeh, in 1965. He said that set theory plays an important role in determining the membership function or a term that is often known in fuzzy, namely the degree of membership [6]. This fuzzy relationship is based on the addition and multiplication obtained from the rules that are still vague and this solution is offered with fuzzy logic in making decisions from an arrangement, from the arrangement of these rules it is also known as the fuzzy arithmetic model. This fuzzy relationship turned out to be a solution to the conclusion drawing system so that theoretical and practical results were obtained [7].

\section{Fuzzy Mamdani}

Mamdani fuzzy logic, in scientific theory, is known as Max-Min. The first to introduce this theory was Ebrahim Mamdani in 1975. The stages in fuzzy Mandani are starting from creating fuzzy sets, designing rules which are often known as rules or other terms. Application of implication functions which are the benchmarks for decision making, the composition of rules, and defuzzification [8].

In the Mamdani fuzzy method there are several steps to be followed, namely:

1. Determine the fuzzy set, to determine the fuzzy set, first determine what variables are included in the input and output variables.

2. Forming the implication function, the implication function uses the AND operator or the OR operator. If using AND, the minimum function is taken, otherwise if the value is OR, the maximum function is taken, then it is connected with the THEN command for the decision to be taken, generally as follows: IF ( $\mathrm{x} 1$ is A1) AND ( $\mathrm{x} 2$ is A2) AND ( $\mathrm{x} 3$ is A3 )... AND ( $\mathrm{xn}$ is An) THEN y is B.

3. Determination of the rule (composition of rules), the composition used using the Mamdani composition or also known as the MAX-MIN rule.

4. Defuzzification

Affirmation is a process of defuzzification in each set, defuzzification is obtained from several fuzzy set variables so that they are connected to the output as the final result obtained is followed up in decision making [9].

Using the Mamdani fuzzy method, the continuous defuzzification variable uses equation (1), while for discrete variables it uses equation (2). The centroid rule is a way of taking the center point of the set [6].

$$
\boldsymbol{\mu}(\boldsymbol{x})=\frac{\int_{a}^{b} x \boldsymbol{\mu}(x) d x}{\int_{a}^{b} x(x) d x}
$$

$$
\mu(x)=\frac{\sum_{i=1}^{n} x_{i} \mu\left(x_{i}\right)}{\sum_{i=1}^{n} \mu\left(x_{i}\right)}
$$




\section{Decision support system}

A decision support system can also be said as a system that provides data modeling to help make a decision that is semi-structured, meaning that one will never know the pattern of decisionmaking on decisions received from certain parties because it cannot be traced with certainty how to produce the given decision. . In this study using Matlab software for testing, the illustration of the test design is shown in Figure 2 below:

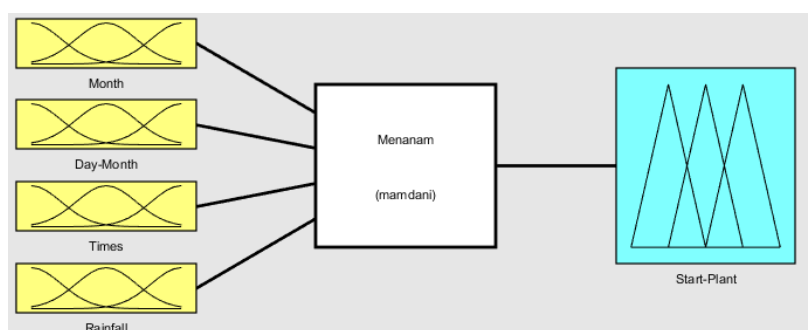

Figure 2. Design Planting Time Decision Making System

In Figure 2 above, the flow of decision-making using the fuzzy method is to collect input variables and then develop rules to get the final decision.

\section{Method}

\section{A. Methodology}

This research uses the Mamdani fuzzy logic method, software with the Windows 10 operating system, and Matlab R2015a software as software for testing data and processing to get output results. This study involved respondents from several sub-districts in South Aceh Regency. Figure 3 below is a flow chart of data testing in decision making with the Mamdani fuzzy method for planting rice in rice plants.

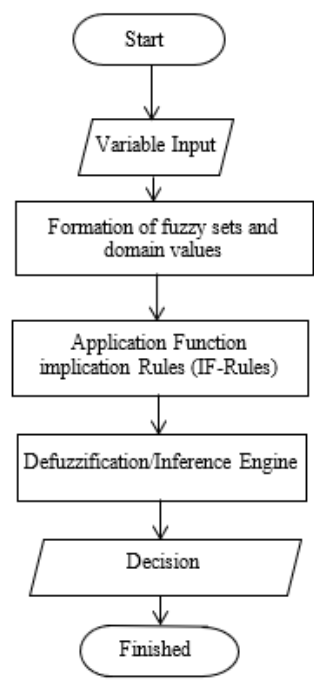

Figure 3. Flowchart of the decision-making system

The process of transforming input to output in the steps of the implementation process can be described as follows:

1. Field survey to get a dataset.

2. Input selection parameters used include:

- Planting Month

- Day-Month

- Planting time

- Rainfall 
3. Output the recommendation is the right time to carry out rice planting activities.

The testing process as above will be repeated until all the data to be tested is inputted. The test is carried out by considering the variables and rules given as a process to get the output value.

\section{B. Research design}

This study was designed using a Mamdani fuzzy logic-based decision-making system as shown in Figure 4 below.

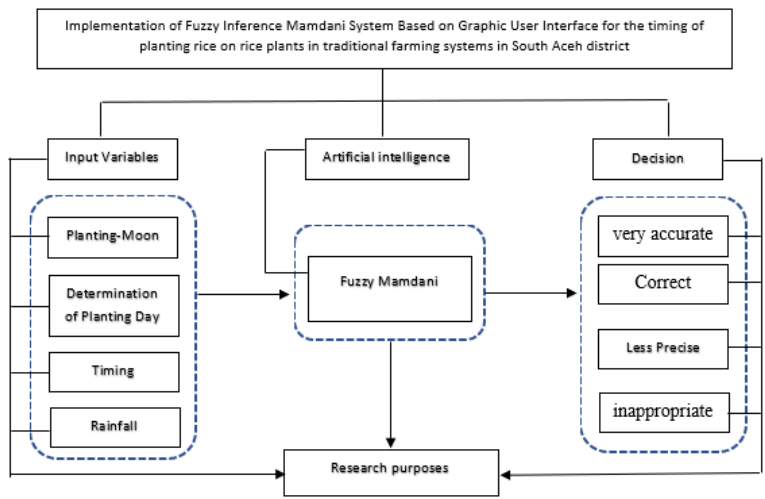

Figure 4. Schematic of the research concept

The scheme in this study as shown in Figure 4 above, shows the research design starting from the title, determining the input variables, the method used using one of the methods in artificial intelligence, the process of defuzzification, and the output obtained in the form of a decision about time. The recommended planting is based on a predetermined classification.

\section{Application function Input implication}

After the fuzzy set is compiled, it is then forwarded to the fuzzy membership implication function. The function application for each input for the dataset can be seen in Figures 5 to 10.

1. Month Variable

Based on the results of interviews with farmers in the field, 6 consecutive months are very good for carrying out rice planting activities including the months of Rabiul Awwal, Rabiul Akhir, Jumadil Awwal, Jumadil Akhir, Safar, and Muharram. because the tradition in traditional Acehnese agriculture uses fragments of the Hijri year. The graph in the month variable can be seen in Figure 5 below.

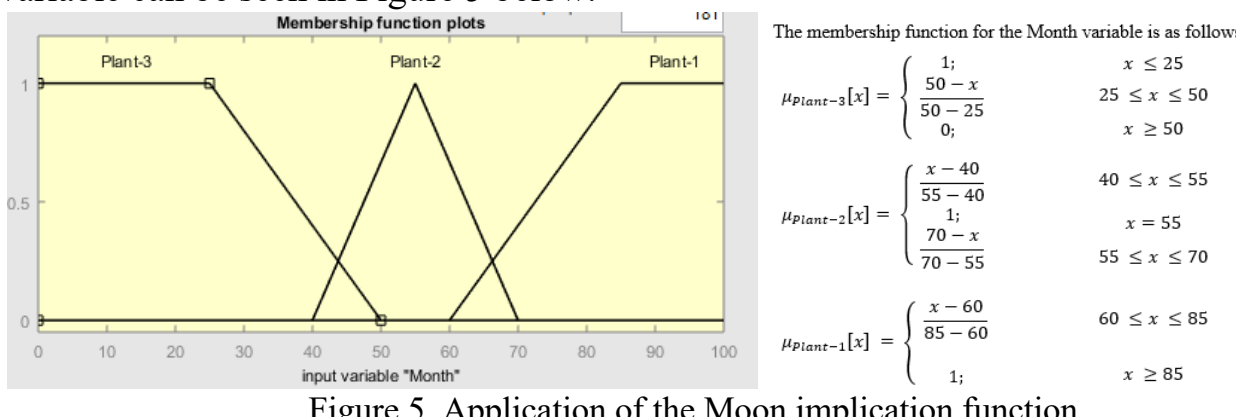

Figure 5. Application of the Moon implication function

The score $[x]$ contained in equation (3.1) to equation (3.19) is the value of the input variable, each input variable has a different equation used, for example, planting month is worth at intervals $25 \leq x \leq 50$ then the implication function uses equation, 3.1 and so on.

2. Variable Day-Month

In traditional Acehnese agriculture, the determination of the lunar day in the Hijri month is used as a reference in the culture of growing rice, as shown in Figure 6 below. 


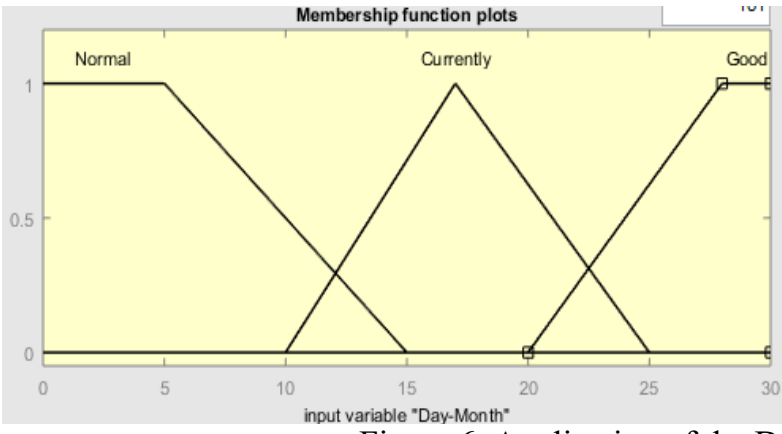

$$
\begin{aligned}
& \text { The membership function for the Day of the Month variable is as follows: } \\
& \mu_{\text {Normal }}[x]=\left\{\begin{array}{cc}
1 ; & x \leq 5 \\
\frac{15-x}{15-5} & 5 \leq x \leq 15 \\
0 ; & x \geq 15
\end{array}\right. \\
& \mu_{\text {Currenty }}[x]=\left\{\begin{array}{cc}
\frac{x-10}{17-10} & 10 \leq x \leq 17 \\
1 ; & x=17 \\
\frac{25-x}{25-17} & 17 \leq x \leq 25
\end{array}\right. \\
& \mu_{\text {Good }}[x]=\left\{\begin{array}{cc}
\frac{x-20}{28-20} & 20 \leq x \leq 28 \\
1 ; & x \geq 28
\end{array}\right.
\end{aligned}
$$

Figure 6. Application of the Day Month variable implication function

3. Variable Planting Time

This variable shows the time used in the process of starting to plant in agricultural activities. The results of the analysis show a graph of the planting time as shown in Graph 7 below.

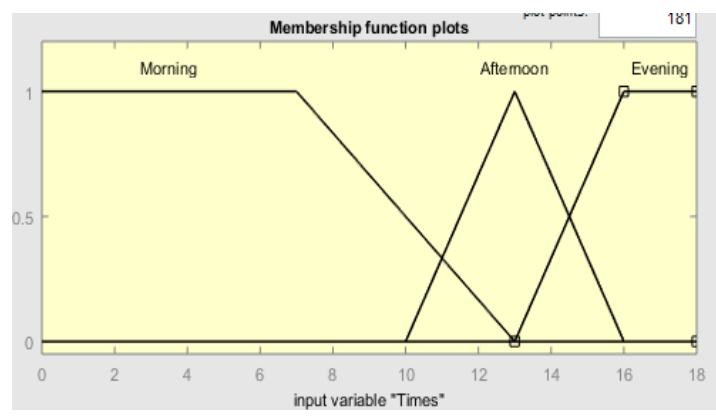

$$
\begin{aligned}
& \text { The membership function for the Planting Time variable is as follows: } \\
& \mu_{\text {Morning }}[x]=\left\{\begin{array}{cc}
1 ; & x \leq 7 \\
\frac{13-x}{13-7} & 7 \leq x \leq 13 \\
0 ; & x \geq 13
\end{array}\right. \\
& \mu_{\text {Afternoon }}[x]=\left\{\begin{array}{cc}
\frac{x-10}{13-10} & 10 \leq x \leq 13 \\
1 ; & x=13 \\
\frac{16-x}{16-13} & 13 \leq x \leq 16
\end{array}\right. \\
& \mu_{\text {Vvening }}[x]=\left\{\begin{array}{cc}
\frac{x-13}{16-13} & 13 \leq x \leq 16 \\
1 ; & x \geq 16
\end{array}\right.
\end{aligned}
$$

Figure 7. Application of the implication function of the planting time variable

\section{Variable Rainfall Value}

For the rainfall variable, this part was not obtained in the field, but the data was taken from the South Aceh district agriculture office. The results of the analysis that have been carried out have compiled a graph for the rainfall intensity variable in this district, the graphic design of this variable can be seen in Figure 8 below.

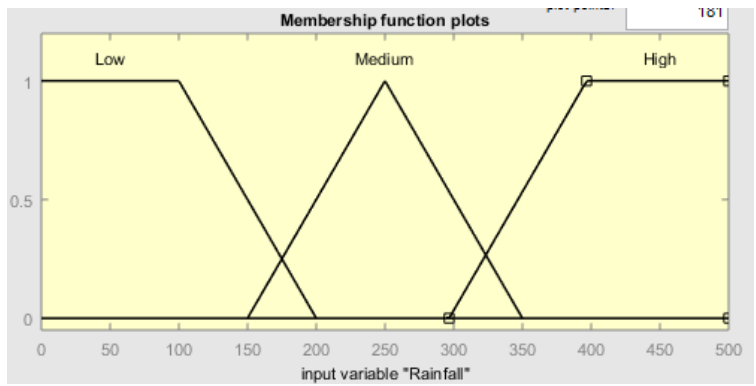

$$
\begin{aligned}
& \begin{array}{l}
\text { The membership function for the Climate/Weather variable is as follows } \\
\qquad x \leq 100
\end{array} \\
& \mu_{\text {Low }}[x]=\left\{\begin{array}{cc}
1 ; & x \leq 100 \\
\frac{200-x}{200-100} & 100 \leq x \leq 200 \\
0 ; & x \geq 200
\end{array}\right. \\
& \mu_{\text {Medium }}[x]=\left\{\begin{array}{cc}
\frac{x-150}{250-150} & 150 \leq x \leq 250 \\
1 ; & x=250 \\
\frac{350-x}{350-250} & 250 \leq x \leq 350
\end{array}\right. \\
& \mu_{\text {High }}[x]=\left\{\begin{array}{cc}
\frac{x-300}{350-300} & 300 \leq x \leq 350 \\
1 ; & x \geq 350
\end{array}\right.
\end{aligned}
$$

Figure 8. Application of the implication function of the Rainfall variable

Of the four types of variables used, then thefuzzificationn process is carried out with predetermined rules to get the decision class from each rule as can be seen in Figure 9 below:
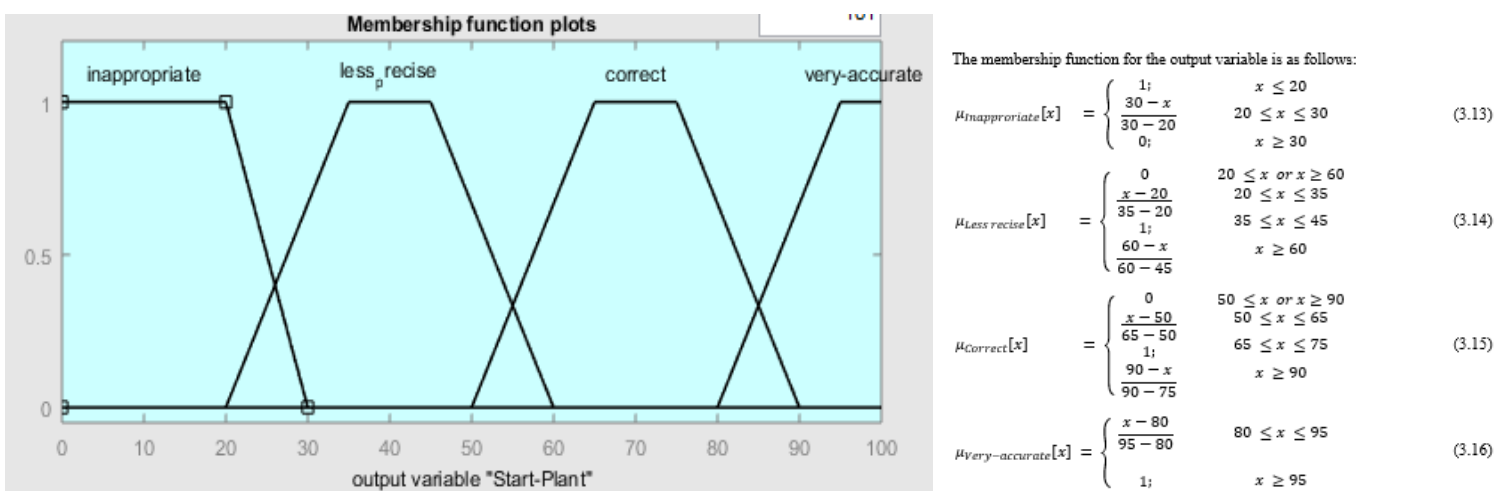
Figure 9. Application of the output Implication function for quiet time decisions

\section{Results and Discussion}

The results of the design of the decision-making program with a GUI, the design of the interface form for the initial appearance of the user, then when the program that has been designed is run, it will appear in the form of an image as shown in Figure 10 below.

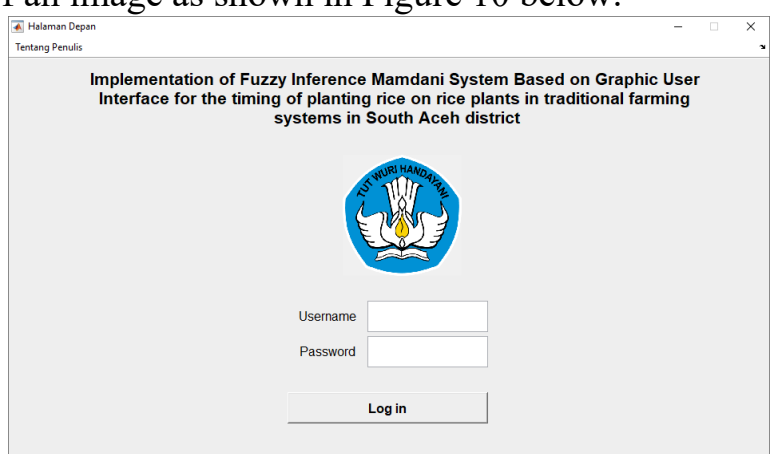

Figure 10. The front page of the planting time decision-making system

The input process as an admin can be done by inputting the overall data from the dataset that has been prepared. For example, if the dataset you have with predetermined variables already exists, run the program by choosing to enter via Admin and proceed with uploading the data from the research survey, then carry out the defuzzification process of the survey data for calculations using the fuzzy system, so that the tests performed by the system appear as shown in Figure 11 below.

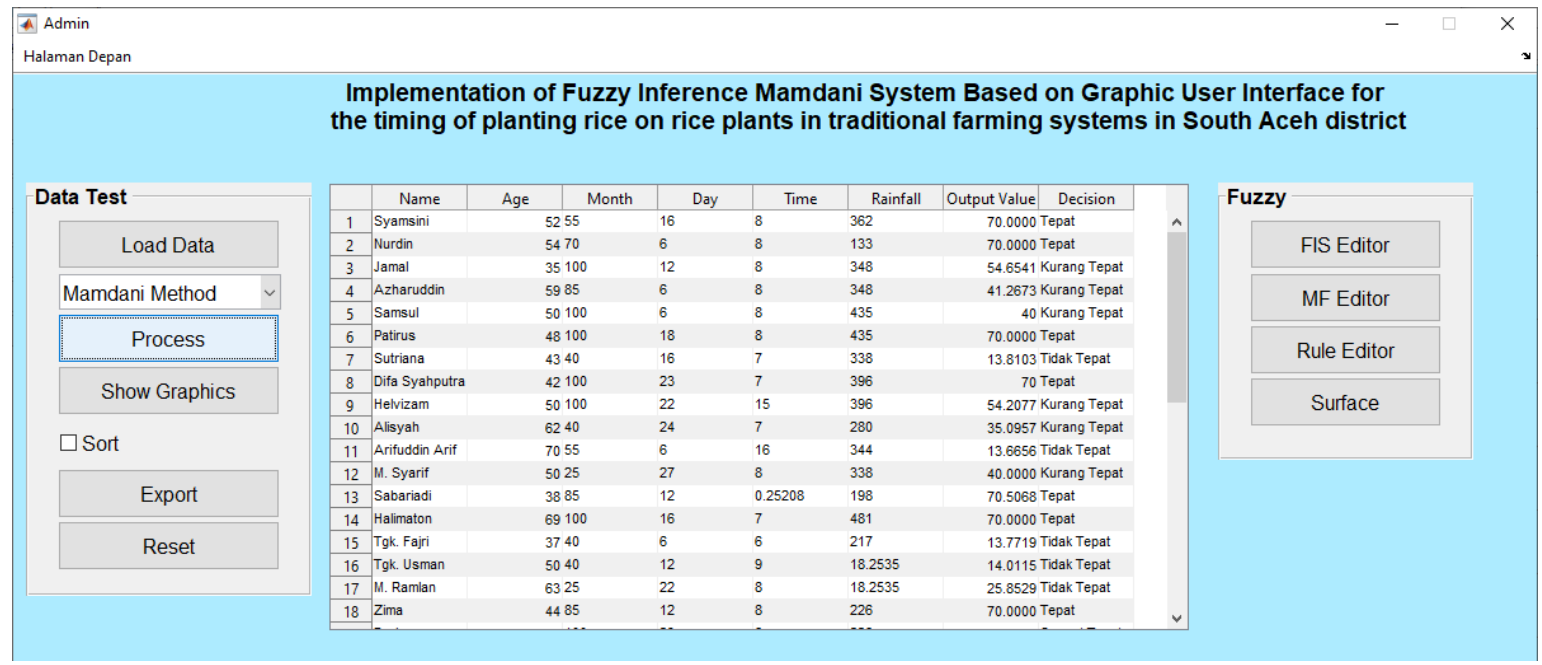

Figure 11. Test results via the admin menu

This test has different graphic values, the value is as much as the data used as research samples, the graph can also be seen in which parts of the decision have a high level of accuracy with parts with low decisions, as in the following graph. 


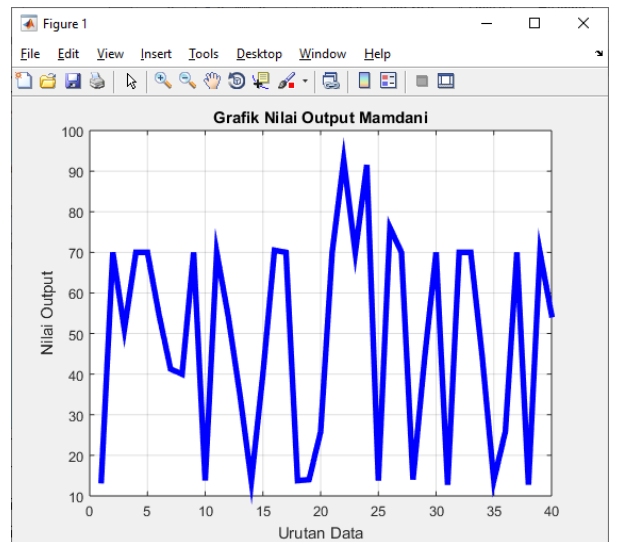

Figure 12. Graph of data testing

From the data that has been tested through admin choices, the data can also be displayed in order from the largest value of the decision results to the smallest decision value, the sequence can be seen in Figure 13 below.

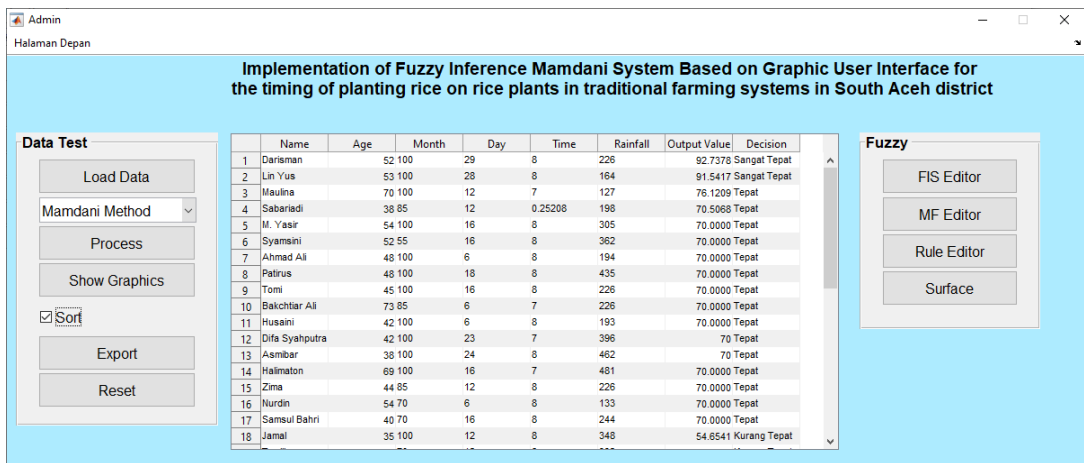

Figure 13. Graph of test data and order of test values

While the process of logging in as a user is tested or someone who wants to see the decision of the input parameters to get the output individually can be done by typing the username as the user as shown in Figure 14 below.

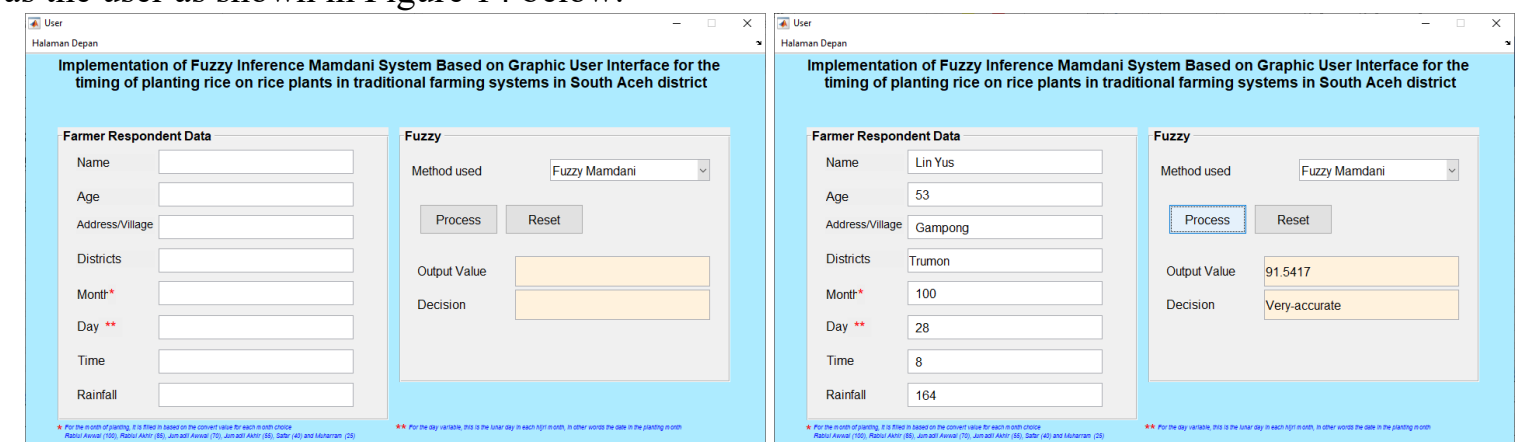

Figure 14. Display options via User and test results

From the tests that have been carried out, someone who wants to start farming activities can determine the right planting time or can be used as a source of information for farming communities to start farming activities. From the results of testing 40 samples of data, tseveral classifications becomedecisions where the results that show very right are 2 people, 16 people are right, 10 people are not quite right and 12 people are not right. The decision to determine the planting time for rice is an implementation of information technology that can be used by people in need. From the test data presented, it can be seen the number of each decision result as shown in Figure 15 below. 

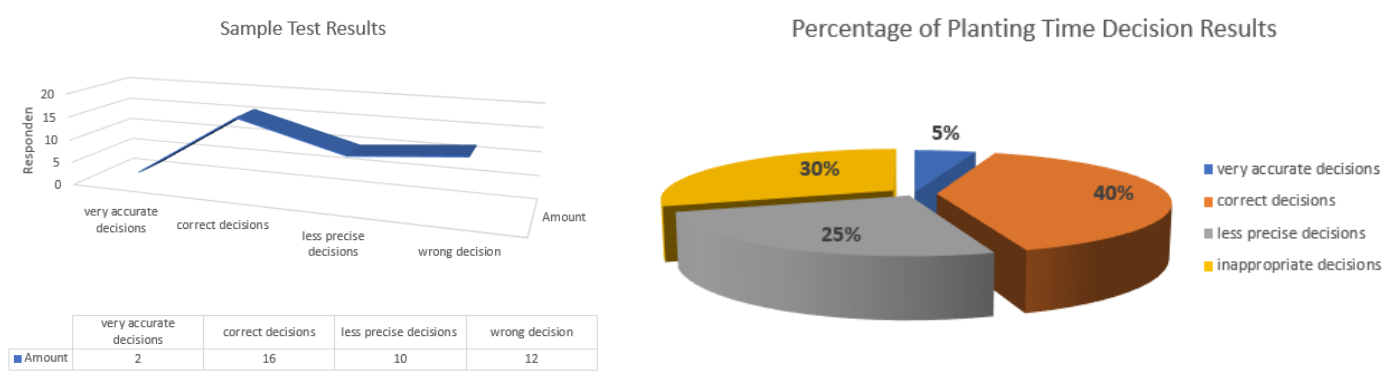

Figure 15. Classification and percentage of test results

From the data above, the results obtained are very accurate decisions of $5 \%$, correct decisions of $40 \%$, less precise decisions of $25 \%$, and the result,s of inappropriate decisions of $30 \%$. The following figure shows the percentage of each decision result obtained.

\section{Conclusion}

Based on research conducted related to the decision-making system when planting rice plants traditionally in South Aceh district using the fuzzy Mamdanii method based on the Graphic User Interface in the selection of planting time, it begins with determining the fuzzy set, determining the application of the implication function, compiling rules that can be used in the fuzzification process to get a firm value of the decision results, from the firm value obtained, it can be determined which category the decision will be taken to take action in starting the planting time on traditional rice plants. The testing process is presented in the form of a Graphic User Interface in Matlab 2015a.

\section{References}

[1] W. N. Adila, R. Regasari, and H. Nurwasito, "Sistem Pendukung Keputusan (SPK) Pemilihan Tanaman Pangan Pada Suatu Lahan Berdasarkan Kondisi Tanah Dengan Metode ELECTRE dan TOPSIS,” J. Pengemb. Teknol. Inf. dan Ilmu Komput., vol. 2, no. 5, pp. 2548-964, 2018.

[2] H. A. Karim and M. Aliyah, "Evaluasi Penentuan Waktu Tanam Padi ( Oriza Sativa L .) Berdasarkan Analisa Curah Hujan Dan Ketersediaan Air Pada Wilayah Bedungan Sekka-Sekka Kabupaten Polewali Mandar," Agrovital, vol. 3, no. 2, pp. 41-46, 2018.

[3] A. Ridha and Sulaiman, "Analisis Pendapatan Petani Padi pada Sistem Tanam Jajar Legowo dan Sistem Tanam Tradisional ( Studi Kasus Pada Kampung Matang Ara Jawa Kec . Manyak Payed ),” $J$. Samudra, vol. 2, no. 2, pp. 108-115, 2018.

[4] K. S. Hariyanti, T. June, Y. Koesmaryono, R. Hidayat, and A. Pramudia, "Penentuan Waktu Tanam dan Kebutuhan Air Tanaman Padi , Jagung, Kedelai dan Bawang Merah di Provinsi Jawa Barat dan Nusa Tenggara Timur," J. Tanah dan Iklim, vol. 43, no. 1, pp. 83-92, 2019.

[5] E. Surmaini and H. Syahbuddin, "Kriteria Awal Musim Tanam: Tinjauan Prediksi Waktu Tanam Padi Di Indonesia," J. Penelit. dan Pengemb. Pertan., vol. 35, no. 2, p. 47, 2016.

[6] Sri Kusumadewi; Hari Purnomo, Aplikasi Logika Fuzzy untuk Pendukung Keputusan. Yogyakarta: Graha Ilmu, 2013.

[7] M. Stetnicha, B. De Baets, and L. Noskova, "Arithmetic fuzzy models," IEEE Trans. Fuzzy Syst., vol. 18, no. 6, pp. 1058-1069, 2010.

[8] A. Yunan and M. Ali, "Study and Implementation of the Fuzzy Mamdani and Sugeno Methods in Decision Making on Selection of Outstanding Students at the South Aceh Polytechnic," J. Inotera, vol. 5, no. 2, pp. 152-164, 2020.

[9] V. Kurniati, D. Triyanto, T. Rismawan, J. Sistem Komputer, and F. H. MIPA Universitas Tanjungpura Jl Hadari Nawawi, "Penerapan Logika Fuzzy Dalam Sistem Prakiraan Cuaca Berbasis Mikrokontroler [1]," J. Coding, Sist. Komput. Untan, vol. 05, no. 2, pp. 119-128, 2017. 